\title{
STRAIN IMPROVEMENT AND EFFECT OF NATURAL INDUCER ON LIPASE PRODUCTION BY RHIZOMUCOR PUSILLUS
}

\author{
Kartiki Kawale, S.Chimurkar, A.A. Fulzele \\ Shri Mathuradas Mohota College of Science, Umrer road, Nagpur-440009 \\ Email: kartikikawale691@gmail.com,kartikikawale2710@gmail.com
}

\begin{abstract}
:
Lipases are widely used enzyme, known for its application in various industries. The fungal strains are preferred for lipase production since their enzymes are secreted extracellular and the extraction technique is simple. Thermophilic fungal enzymes are more important because of their stability at high temperature. During present investigation a thermophilic fungi Rhizomucour pusillus was isolated from decomposing leaves collected from forest of Nagpur district. Strain improvement of $R$. pusillus was carried out the increase Lipase production by using chemical mutagen EMS. Mutant strains derived were evaluated for yield of lipases production. Lipase activity of mutants was assayed by evaluation of quantity of fatty acid released in unit time during enzyme reaction and its measured by the quantity of $\mathrm{NaOH}$ required to maintain $\mathrm{pH}$ neutral. Present work also includes the effect of natural inducer such as wheat bran and olive oil on lipase production. It was concluded that the wheat bran is good inducer for lipase production as compare to olive oil during the process of submerged fermentation.
\end{abstract}

Keywords: Strain improvement lipase activity, inducer, fungi, Rhizomucour pusillus

\section{INTRODUCTION:}

Lipases are widely used enzyme, known for its applications in various industries. The fungal strains are preferred for lipase production since their enzymes are secreted extracellular and the extraction technique is simple. Thermophilic fungal enzymes are more important because of their stability at high temperature. Present investigation on a thermophilic fungus Rhizomucor pusillus (Lindt) Schipper was isolated from decomposing leaves collected from forest of Nagpur district. Mutant was developed earlier in same laboratory by using EMS. Quantitative estimation of lipase was carried out to understand effect of natural inducer during fermentation on lipase production.

Lipases are widely used enzyme, known for its applications in various industries. The fungal strains are preferred for lipase production since their enzymes are secreted extracellular and the extraction technique is simple. Thermophilic fungal enzymes are more important because of their stability at high temperature. Present investigation on a thermophilic fungus Rhizomucor pusillus (Lindt) Schipper was isolated from decomposing leaves collected from forest of Nagpur district. Mutant was developed earlier in same laboratory by using EMS. Quantitative estimation of lipase was carried out to understand effect of natural inducer during fermentation on lipase production.

Rhizomucor pusillus - It is a thermophilic fungus that lives in hot environments such as decomposing leaf litter. Its growth optimum at $45^{\circ} \mathrm{C}$ and a maximum temperature $50^{\circ} \mathrm{C}$ or above and a minimum of $20^{\circ} \mathrm{C}$ or above (Cooney Emerson, 1964, Maheshwari et al., 2000). Rhizomucor pusillus structure shows rhizoids and branched sporangiophores. It is grey mycelium fungi grows naturally on dead and decaying 
materials, most commonly found on composting and leaf litter during thermophilic phase of decomposition.

Classification: Kingdom-Emycota,DivisionZygomycota,Class-Zygomycets, Order-Mucorales, Family -Mucoraceae,

Genus-Rhizomucor,

Species-pusillus

\section{Lipase:}

- The hydrolysis of fats (lipids) catalyzes through an enzyme known as lipase.

- Lipase plays an important part in the processing, transport and digestion of dietary lipids (e.g. oils, fats, Triglycerides).

- In an oil-water interfaces, hydrolysis of free fatty acids and glycerol from triglycerides are done through hydrolysed under which lipases (triacylglycerol acylhydrolases: EC 3.1.1.3) is one of the category.

- Also, lipases catalyze the hydrolysis and transesterification of other esters as well as the synthesis of esters and exhibit enantio selective properties.

- Lipases becomes famous in most of the common used product such as detergent, food, cosmetic, pharmaceutical industries and organic synthesis due to its ability of chemical transformation (biotransformation).

- Recently many various plan of action in the chemical and pharmaceutical industries have use lipase in the synthesis of unblended drugs and agrochemicals (M. De M.D Maia et al., 1999).

\section{MICROBIAL SOURCES OF LIPASES:-}

- Lipases are omnipresent in nature and are manufactured by various microorganisms, animals, and plants. The most widely extensively used class of enzymes in organic chemistry and biotechnological applications are lipases have microbial origin. A review of the most recent (from 2004 to the present) potential microorganisms for lipase production in submerged fermentation.

\section{FUNGI:-}

- Most commercially important lipaseproducing fungi are recognized as belonging to the genera Geotrichum sp., Mucor sp., Rhizomucor sp., Aspergillus sp., Fusarium sp., Humicola sp., etc. (Cihangir and Sarikava, 2004).

- Due to intense industrial application, new enzymes with specific characteristics in various branches of industrial activity is huge, therefore identification of novel enzymes with desired characteristics in relation to the substrate selectivity, thermo stability, $\mathrm{pH}$ and temperature optimum and optimization of its production resulting directly in reduced cost.

\section{APPLICATION OF LIPASE:-}

Lipases are generally apply in the processing of detergents and degreasing formulations, oils and fats, the synthesis of fine chemicals and pharmaceuticals, manufacturing of paper, processing of food, and cosmetic production (Rubin and Dennis,1997). The degradation of fatty waste (Masse etal, 2001) mostly accelerated by the use of Lipase. Fungi and bacteria derived the industrial microbial lipases. In 2002, the industrial market value for lipases was reported as 1.5 billion US dollars (Alain Houde etal.2004. Industrial applications of microbial lipases (Vulfson, 1994).

Present work:- Focus on factors relevant for the enhancement of enzymatic hydrolysis of triacylglycerols compounds using lipase extracted from thermophilic fungus Rhyzomucor pusillus and to study effect of mutagen on production of cellulase by evaluating cellulase activity of mutants generated. 
Lipase [triacylglycerol acylhydrolase, EC 3.1.1.3] is omnipresent enzymes of substantial physiological significance and industrial potential. It catalyse the hydrolysis of triacylglycerols to glycerine and free fatty acids.

1. Isolation of thermophilic fungus Rhizomucor pusillus from samples of decomposing leaf litter collected from forest of Nagpur district.

2. Strain improvement of Rhizomucor pusillusby chemical mutagenesis for increased Lipase production by using chemical mutagen Ethyl Methane Sulphonate (EMS).

3. Mutants clones to be obtained by the mutagenesis program stabilize by culturing for minimum six generation.

4. Mutants derived by EMS treatment will be evaluated for yield of lipases. Lipase activity of Mutants was assayed for evaluation by the quantity of fatty acid released in unit time is measured by the quantity of $\mathrm{NaOH}$ required to maintain $\mathrm{pH}$ constant (Jayraman, J. (1981).

\section{MATERIAL \& METHODS:}

\section{Isolation of thermophilic fungi:-}

Thermophilic fungi were isolated from samples of decomposing leaf litter collected from forest of Nagpur district.

Isolation techniques were used:- By (Waksman et al 1931; Waksman et al. 1939). The hyphal isolates were sub-cultured onto yeast starch (YpSs) agar (Cooney et al.1964) until pure cultures were obtained.

\section{Procedure lipase assay:- By Jayraman, J. (1981):-}

$2 \mathrm{ml}$ of olive oil, neutralize to $\mathrm{pH} 7.0$, and stir well with $100 \mathrm{mg}$ bile salt, i.e. sodium taurocholate and $25 \mathrm{ml}$ of water. Addition of $2 \mathrm{gm}$ gum tragacanth has tens emulsification. Set the beaker on top of magnetic stirrer (cum hot plate) and stirrer the content slowly. Make $0.1 \mathrm{~N} \mathrm{NaOH}$ and $50 \mathrm{mM}$ phosphate buffer ( $\mathrm{pH}$ 7.0). Lipase activity was determine by titrimetric method given by method (Jayraman, J. 1981); using Olive oil (Hi-media) as substrate emulsion. Crude enzyme was extracted from YpSs broth having six days old pure culture of Rhizomucor pusillus. Take centrifuge tubes and added the $1 \mathrm{ml}$ phosphate buffer, $2 \mathrm{ml}$ double distilled water and $3 \mathrm{ml}$ substrate containing homogenized $2 \mathrm{ml}$ olive oil, $2 \mathrm{~g}$ gum tragacanth, $25 \mathrm{ml}$ double distilled water ( $\mathrm{pH}$ maintain 7.0 stir the contents slowly). Note the room temperature; Dip the electrodes of $\mathrm{pH}$ meter in the reaction mixture. Note the $\mathrm{pH}$ and adjust to 7.0. Take centrifuge tube add $3 \mathrm{ml}$ substrate, $1 \mathrm{ml}$ phosphate buffer, $2 \mathrm{ml}$ double distilled water and add $1 \mathrm{ml}$ Crude enzyme. Instantly record the $\mathrm{pH}$ and set the timer on. Let it be $\mathrm{pH}$ at zero, ( $\mathrm{pH}$ maintain to 7.0). Dip the electrodes of ph meter in the reaction mixture. Note the $\mathrm{pH}$ and adjust it to 7.0. After $30 \mathrm{~min}$ again dip the electrode to take the $\mathrm{pH}$ reading and added drops of $0.1 \mathrm{~N} \mathrm{NaOH}$ to bring $\mathrm{pH}$ to the initial value.

Note:- The volume of alkali consumed.

3. Effect of additives growth:- In $R$. pusillus fungus are have to show the effect of additive growth for that use additive wheat bran in different percentage $(2 \% \& 4 \%)$. We take the two set of petriplate pore the YpSs media then add with $2 \%$ and $4 \%$ additive. After that inoculate the fungi and day by day observed and measure the growth of colony.

\section{RESULTS \& DISCUSSION:}

Isolation of thermophilic fungus Rhizomucor pusillus from samples of decomposing leaf litter collected from forest of Nagpur district.

Genetic improvement of Rhizomucor pusillus through mutation:- At $10 \mathrm{mg} / \mathrm{ml}$ EMS 
concentration able to generate mutants with about survivability percentage near or less than $1 \%$ and it is the requirement to generate mutants in fungi. Effective duration of exposure to EMS solution for fungus which is able to produce successful mutants was finding of 90 minutes and 120 minutes. Isolation of mutant after treatment of EMS. After the treatment of mutagen EMS, mutants pure cultured up to minimum six generations through spores for stabilization.

The production of lipase and estimation of enzyme was carried out quantitatively by evaluating the enzymes complex.

\section{Effect lipase production using wheat bran and} olive oil as inducer by submerged

fermentation:- Enzyme extracted for lipase estimation from submerged fermentation using various inducer to enhance lipase activity where a incubated at $45 \mathrm{C}$ for 5days. Control was taken without inducer. Pure culture of fungus was inoculated during submerged fermentation. Crude enzyme extract kept at $4^{\circ} \mathrm{C}$ till the procedure for assay started for lipase assay, (Jayraman, J .1981). When three $\mathrm{ml}$ enzyme use during the lipase activity. shows that the amount of $\mathrm{NaOH}$ required to neutralized substrate compared with control (without inducer), it shows $37 \%$ rise in enzyme activity with inducer as olive oil and with wheat bran $40 \%$ more enzyme activity, (Fig.No.2, Table No3). Wheat bran showed 3\% more activity than olive oil as inducer.

\section{B. Effect on enzyme production at different} interval of time such as 5 days and 10 days:-

During enzyme assay when one $\mathrm{ml}$ enzyme used from the set of five days of incubation where wheat bran was inducer, shows $\mathrm{NaOH}$ required to neutralize fatty acid with inducer $14 \%$ equal to control no substantial increase in enzyme activity. After ten days of incubation lipase activity shown, 60\% increased as compared to control (Table No: 4, Fig. No.3)

Olive oil use as inducer:- When Olive oil use as inducer, and five days of incubation enzyme activity was shown $6.15 \%$ increase as compared to control. When one $\mathrm{ml}$ enzyme used during enzyme assay. When results of wheat bran and olive oil as inducer to enhance lipase activity, compared with control olive oil shown about $6 \%$ rise in enzyme production during five days of incubation.

\section{Effect of wheat bran as additive on growth of} R. pusillus:-

Growth of $R$. pusillus on solid nutrient medium with wheat bran as additive when compared with normal YpSs Emersion Agar medium. On second day as compared to control $0.20 \%$ growth rise found in two percent (2\%) wheat bran as additive in nutrient medium. When four percent (4\%) wheat bran was used as additive in nutrient medium rise was $0.22 \%$ this result indicated present wheat bran in nutrient medium favours fungal growth in a substantial way.(Table no.5,Fig.no.4,Plate no.2/3).

\section{CONCLUSION}

Experiment was Carry out with the aim to developed fungi with better capacity to produce lipase and industrially important enzyme through mutagenesis of $R$. pusillus. Success fully mutants of $R$. pusillus develop by Chemical mutagen EMS. Thermophilic fungus selected for enzyme production because such enzymes are thermo-stable which is an essential requirement for industrial utilization Jayraman, J.(1981) method is cost effective and less time consuming technique to evaluate lipase activity.

In the present work following techniques were standardized. Isolation of thermophilic fungi, Chemical mutagenesis, stabilization of mutant fungal strains, extraction and estimation of lipase enzyme activity. Effect of inducer such as olive oil 
and wheat bran was observed during submerges fermentation under investigation to enhance lipase production from selected mutant. For selected mutant strain of Rhizomucor pusillus, showed Wheat bran as more effective inducer for lipase production during submerged fermentation when compared with olive oil used as inducer. Results showed consistency that rise in growth of $R$. pusillus on solid nutrient medium with wheat bran as additive when compared with normal YpSs Emersion Agar medium. During the investigation it has been observed that crude Enzyme concentration is an important factor during enzyme activity analysis. Low concentration of crude enzyme do not shows sufficient activity on substrate, purification of enzyme is essential for analysis of Lipase activity. All above parameters must be further analyzed in detail to optimize the lipase production.

\section{ACKNOWLEDGMENT}

I am deeply obliged to principal Dr. S. G. Charlawar, vice principal Dr. Rina Saha. Shri Mathuradas Mohota College of Science Nagpur, for their constructive and constant encouragement throughout the progress of the work and for providing all the necessary facilities and financially support during this work.

\section{REFERENCES:}

Alain Houde, Ali Kademi, Danielle Leblanc. Lipase and their industrial application, Appl Biochem Biotechnol,2004;118(1):155-170.

Brockman, H.L. and Borgstorm, B. (1984) Lipases, Elsevier, Amsterdam. pp. 34.

Cihangir and Sarikaya E.2004. Investigation of lipase producti on by a new isolate of Aspergillus sp. World J Microbiol Biotechnol.20(2):193-197.
Cooney, D. G. Emerson, R. 1964. Thermophilic fungi. Publ. San Francisco. 1-188.

Jayraman, J. (1981) JaegerK.E., B.W. Dijkstra, M.T. Reetz, Bacterial Biocatalysts: Molecular biology, three-dimensional structures, and biotechnological applications, Annu. Rev. Microbiol. 53 (2000) 315-351.

Jayraman, J. (1981), in Laboratory manual in Biochemistry Wiley Eastern Limited New Delhi P. 133.

Maheshwari R., Bharadwaj, G. Bhat, M. K. 2000. Thrtmophilic fungi: their physiology and enzymes. Microbiol. Mol. Biol. Rev. 64 (3): pp.461-488.

M. De M.D Maia, Morais, M.M.C.D., Morais, M.A.D., Melo, E.H.M. and Filho,J.L.D.L. 1999. Production of extracellular lipase by the phytopathogenic fungus Fusariumsolani FS1. Rev. Microbiol., 30(4):304-309.

Masse L,Kennedy KJ, Chou SP. The effect of an enzymatic preteatment on the hydrolysis and size reduction of fat particles in slaughter house waste water. J Chem Technol Biotechnol 2001; 76:629-35.

Rubin and Dennis,1997.editors. Lipase: Part A. Biotechnology Methods in enzymology.vol. 284. New York: Academic Press, pp.1-408.

Vulfson, E.N. 1994. Industrial application of lipase. In: Woolley P, PETERSEN SB, editors. Lipases their structure, biochemistry and application. Cambridge, UK: Cambridge university press,271-288.

Waksman et al 1931; Waksman et al 1939, where two acyl moieties are exchanged between two acylglycerols (Balcao et al 1996). 643 R. Sharma et al/ Biotechnology advance (2001) 627-662. 


\begin{tabular}{|c|c|c|}
\hline Industry & Action & Product $\&$ its application \\
\hline a) Dairy foods & $\begin{array}{l}\text { Hydrolysis of milk fat, cheese } \\
\text { ripening, modification of butter } \\
\text { fat }\end{array}$ & $\begin{array}{l}\text { Development of flavouring } \\
\text { agents in milk, cheese, and } \\
\text { butter }\end{array}$ \\
\hline b) Bakery foods & Flavour development & Shelf-life elongation \\
\hline c) Pharmaceuticals & Trans esterification; hydrolysis & Speciality lipids, digestive acids \\
\hline d) Libation & Improved aroma & Beverages \\
\hline e) Cleaner & Hydrolysis of fats & $\begin{array}{l}\text { Expulsion of oil stains from } \\
\text { fabrics }\end{array}$ \\
\hline f) Food dressing & Quality development & $\begin{array}{l}\text { Mayonnaise, dressings, and } \\
\text { whippings }\end{array}$ \\
\hline g) Meat and fish & Flavour development & $\begin{array}{l}\text { Meat and fish products, fat } \\
\text { removal }\end{array}$ \\
\hline h) Health food & Trans etherification & Health food \\
\hline i) Meat and fish & Flavour development & $\begin{array}{l}\text { Meat and fish products, fat } \\
\text { removal }\end{array}$ \\
\hline j) Fats and oils & Trans esterification; hydrolysis & $\begin{array}{l}\text { Cocoa butter, fatty acids, } \\
\text { glycerol }\end{array}$ \\
\hline k) Cosmetics & Synthesis & Emulsifiers, moisturizers \\
\hline 1) Leather & Hydrolysis & Leather products \\
\hline m) Paper & Hydrolysis & Paper with improved quality \\
\hline n) Cleaning & Hydrolysis & Removal of fats \\
\hline
\end{tabular}

\begin{tabular}{|l|l|l|l|}
\hline Table No. 2. Isolation of mutant after treatment of mutagen EMS \\
\hline EMS treatment & $\begin{array}{l}\text { No of Colonies } \\
\text { survive after } \\
\text { 90min. of EMS } \\
\text { treatment }\end{array}$ & $\begin{array}{l}\text { No of Colonies } \\
\text { survive after 120 } \\
\text { min. of EMS } \\
\text { treatment }\end{array}$ & $\begin{array}{l}\text { Control } \\
\text { Colonies count }\end{array}$ \\
\hline $10 \mathrm{mg} / \mathrm{ml}$ & 40 colonies & 11 colonies & 79,2000 \\
\hline Percent survivability & $0.005 \%$ & $0.0013 \%$ & $100 \%$ \\
\hline
\end{tabular}

\begin{tabular}{|c|c|c|c|c|c|c|c|c|}
\hline \multicolumn{9}{|c|}{$\begin{array}{c}\text { Table No, 3:-Estimation of Lipase activity of Mutant=M90 D1 Of Rhizomucor pusillus (used } 5 \mathrm{ml} \mathrm{\&} \mathrm{3ml} \\
\text { enzyme) treatment }\end{array}$} \\
\hline \multirow{5}{*}{$\begin{array}{c}\text { 5ML } \\
\text { ENZYME USE } \\
\text { AS A } \\
\text { REACTANT }\end{array}$} & & \multicolumn{2}{|c|}{ WHEAT BRAN } & \multirow[b]{2}{*}{$\begin{array}{l}\mathbf{N} \\
\mathbf{O}\end{array}$} & \multicolumn{2}{|c|}{ OLIVE OIL } & \multicolumn{2}{|c|}{ Mutant without additive } \\
\hline & $\begin{array}{l}\mathbf{N} \\
\mathbf{O}\end{array}$ & $\begin{array}{c}\mathrm{NaOH} \\
\text { required } \\
(\mathrm{ml})\end{array}$ & $\begin{array}{c}\text { Mean } \\
(\mathrm{ml})\end{array}$ & & $\begin{array}{c}\mathrm{NaOH} \\
\text { required } \\
(\mathrm{ml})\end{array}$ & Mean & NO & Mean \\
\hline & 1 & 2.3 & \multirow{3}{*}{$\begin{array}{c}1.95 \\
( \pm 0.308 \\
\quad)\end{array}$} & 1 & 1.7 & \multirow{3}{*}{$\begin{array}{c}1.88 \\
( \pm \mathbf{0 . 1 4})\end{array}$} & \multirow{3}{*}{1} & \multirow{3}{*}{$\begin{array}{c}1.66 \\
( \pm 0.05)\end{array}$} \\
\hline & 2 & 2.0 & & 2 & 1.9 & & & \\
\hline & 3 & 1.55 & & 3 & 2.06 & & & \\
\hline \multirow{3}{*}{$\begin{array}{c}\text { 3ML } \\
\text { ENZYME USE } \\
\text { AS A } \\
\text { REACTATNT }\end{array}$} & & & \multirow{3}{*}{$\begin{array}{c}1.35 \\
( \pm 0.49)\end{array}$} & & & \multirow{3}{*}{$\begin{array}{c}0.8 \\
( \pm 0.28)\end{array}$} & \multirow{3}{*}{1} & Mean \\
\hline & 1 & 1.7 & & 1 & 0.6 & & & \multirow{2}{*}{$\begin{array}{c}1.25 \\
( \pm 0.07)\end{array}$} \\
\hline & 2 & 1.0 & & 2 & 1 & & & \\
\hline
\end{tabular}




\begin{tabular}{|c|c|c|c|c|c|c|c|c|c|c|c|c|}
\hline & \multicolumn{4}{|c|}{ CONTROL WITHOUT ADDITIVE } & \multicolumn{4}{|c|}{$\begin{array}{c}\text { M90-D1 FUNGI WITH WHEAT } \\
\text { BRAN } 2 \%\end{array}$} & \multicolumn{4}{|c|}{$\begin{array}{l}\text { M90-D1 FUNGI WITH WHEAT } \\
\text { BRAN 4\% }\end{array}$} \\
\hline & \multicolumn{2}{|c|}{ DAY 1} & \multicolumn{2}{|c|}{ DAY 2} & \multicolumn{2}{|c|}{ DAY 1} & \multicolumn{2}{|c|}{ DAY2 } & \multicolumn{2}{|c|}{ DAY1 } & \multicolumn{2}{|c|}{ DAY2 } \\
\hline & $\begin{array}{l}\text { Colony } \\
\text { Diameter }\end{array}$ & Mean & $\begin{array}{l}\text { Colony } \\
\text { Diameter }\end{array}$ & Mean & $\begin{array}{l}\text { Colony } \\
\text { Diameter }\end{array}$ & Mean & $\begin{array}{c}\text { Colony } \\
\text { Diamet } \\
\text { er }\end{array}$ & Mean & $\begin{array}{l}\text { Colony } \\
\text { Diameter }\end{array}$ & Mean & $\begin{array}{c}\text { Colony } \\
\text { Diamet } \\
\text { er }\end{array}$ & Mean \\
\hline 1 & $6.6 \mathrm{~mm}$ & \multirow{3}{*}{$\begin{array}{c}\frac{7.3}{\mathrm{~mm}} \\
\frac{ \pm}{0.62} \\
1\end{array}$} & $\begin{array}{c}17.8 \mathrm{~m} \\
\mathrm{~m}\end{array}$ & \multirow{3}{*}{$\begin{array}{c}\frac{17.8}{6 m} \\
\frac{6 m}{( \pm} \\
0.20 \\
1\end{array}$} & $\begin{array}{c}10.1 \mathrm{~m} \\
\mathrm{~m}\end{array}$ & \multirow{3}{*}{$\begin{array}{c}\frac{9.77}{\mathrm{~mm}} \\
\frac{ \pm}{0.57} \\
1\end{array}$} & $\begin{array}{c}20.9 m \\
m\end{array}$ & \multirow{3}{*}{$\frac{20.73}{\frac{\mathrm{mm}}{( \pm}}$} & $9.8 \mathrm{~mm}$ & \multirow{3}{*}{$\begin{array}{l}\frac{10.3}{\mathrm{~mm}} \\
0.81)\end{array}$} & $\begin{array}{l}23.7 \mathrm{~m} \\
\mathrm{~m}\end{array}$ & \multirow{3}{*}{$\begin{array}{c}\frac{22.8}{\mathrm{~mm}} \\
\frac{\sharp}{0.66)}\end{array}$} \\
\hline 2 & $7.5 \mathrm{~mm}$ & & $\begin{array}{l}18.1 \mathrm{~m} \\
\mathbf{m}\end{array}$ & & $\underset{\mathbf{m}}{10.1 \mathrm{~m}}$ & & $\begin{array}{c}20.7 m \\
m\end{array}$ & & $\begin{array}{l}11.3 m \\
\mathbf{m}\end{array}$ & & $\begin{array}{l}22.6 \mathrm{~m} \\
\mathrm{~m}\end{array}$ & \\
\hline 3 & $7.8 \mathrm{~mm}$ & & $\begin{array}{c}\mathbf{1 7 . 7 m} \\
\mathbf{m}\end{array}$ & & $9.1 \mathrm{~mm}$ & & $\begin{array}{c}20.6 \mathrm{~m} \\
\mathrm{~m}\end{array}$ & & $10 \mathrm{~mm}$ & & $\begin{array}{l}22.1 \mathrm{~m} \\
\mathrm{~m}\end{array}$ & \\
\hline \multicolumn{2}{|c|}{ Difference } & $\begin{array}{c}0.07 \\
3 \%\end{array}$ & \multicolumn{2}{|c|}{$0.17 \%$} & \multicolumn{2}{|c|}{$0.09 \%$} & \multicolumn{2}{|c|}{$0.20 \%$} & \multicolumn{2}{|c|}{$0.10 \%$} & \multicolumn{2}{|c|}{$0.22 \%$} \\
\hline & $\theta$ & 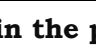 & & & & & & & & & & \\
\hline
\end{tabular}

Table No. 4:- Estimation of Lipase activity of Mutant=M90 D1 Of Rhizomucor pusillus ( after 5days and 10 days comparatively) treatment

\begin{tabular}{|c|c|c|c|c|c|}
\hline \multirow{5}{*}{$\begin{array}{c}5 \\
\text { DAYS }\end{array}$} & \multirow[b]{2}{*}{ No } & \multicolumn{2}{|c|}{ WHEAT BRAN } & \multicolumn{2}{|c|}{ Mutant without additive } \\
\hline & & $\begin{array}{l}\text { NaOH required } \\
(\mathrm{ml})\end{array}$ & Mean & $\begin{array}{l}\text { NaOH required } \\
\text { (ml) }\end{array}$ & Mean \\
\hline & 1 & 0.26 & \multirow{3}{*}{$\begin{array}{c}0.21 \\
( \pm 0.061)\end{array}$} & 0.2 & \multirow{3}{*}{$\begin{array}{l}0.26 \\
( \pm 0.04)\end{array}$} \\
\hline & 2 & 0.13 & & 0.3 & \\
\hline & 3 & 0.26 & & 0.3 & \\
\hline \multirow{3}{*}{$\begin{array}{c}10 \\
\text { DAYS }\end{array}$} & 1 & 1.00 & \multirow{3}{*}{$\begin{array}{c}0.89 \\
( \pm 0.100)\end{array}$} & 0.1 & \multirow{3}{*}{$\begin{array}{c}0.2 \\
( \pm 0.094)\end{array}$} \\
\hline & 2 & 0.76 & & 0.3 & \\
\hline & 3 & 0.93 & & 0.3 & \\
\hline \multicolumn{6}{|c|}{ NOTE:- Values in the parenthesis are Standard deviation } \\
\hline
\end{tabular}

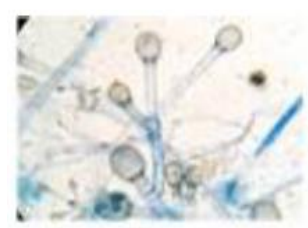

A- Branching pattern of Rhizomucor pusillus

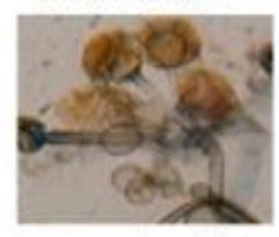

C-Sporangia with Spores of $R$. pusillus

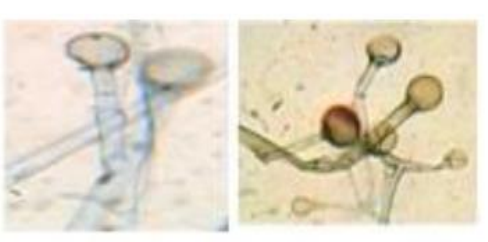

B- Collar regions R. pusillus

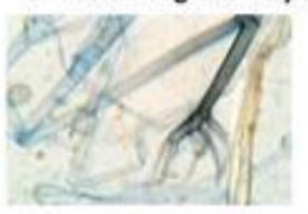

D-Rhizoids of $R$. pusillus

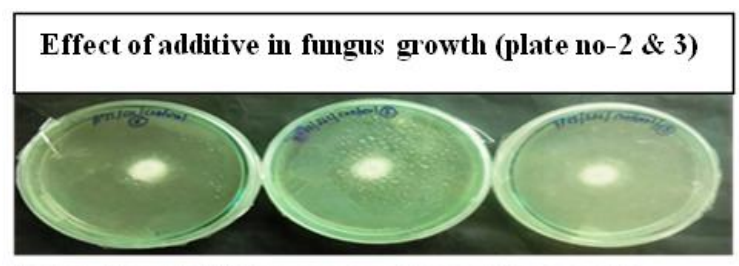

Plate 1-Growth of Rhizomucor pusillus on YpSs agar with control without wheat bran

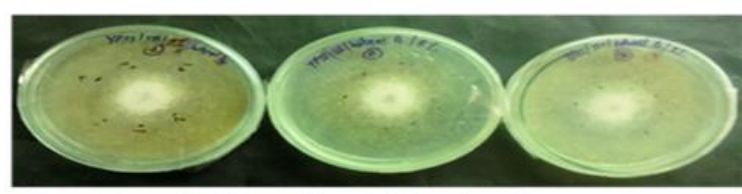

Plate 2-Growth of R. pusillus with $2 \%$ wheat bran

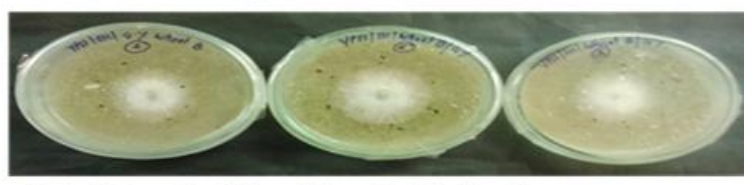

Plate 3-Growth of R. pusillus with $4 \%$ wheat bran 
Fig. no:1 Lipase activity of $R$. pusillus M90 mutant $5 \mathrm{ml}$ enzyme used and wheat bran and olive oli used as inducer in terms of $\mathrm{NaOH}$ $(\mathrm{ml})$ required to neutralizd fatty acid.

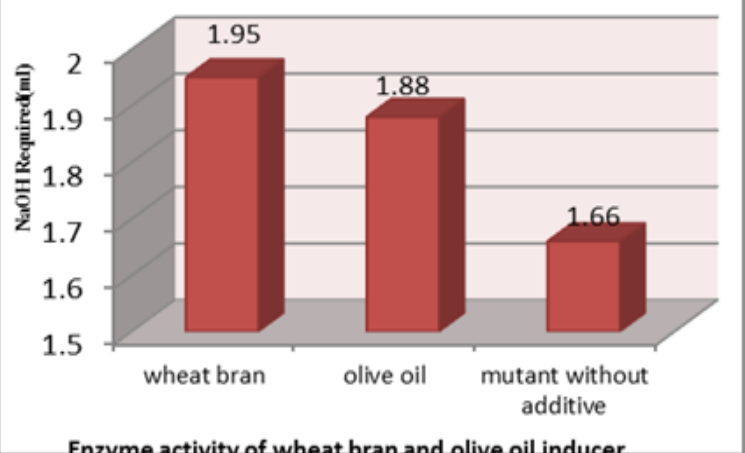

Enzvme activitv of wheat bran and olive oil inducer

Fig.no: 3 Effect of wheat bran after 5 days and 10 days $(1 \mathrm{~m} /$ )enzyme used comparative

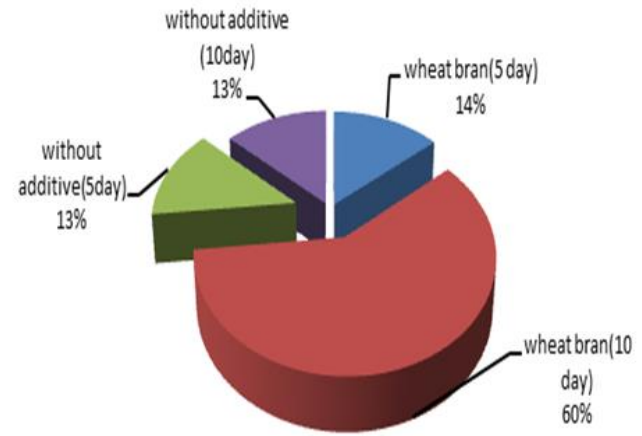

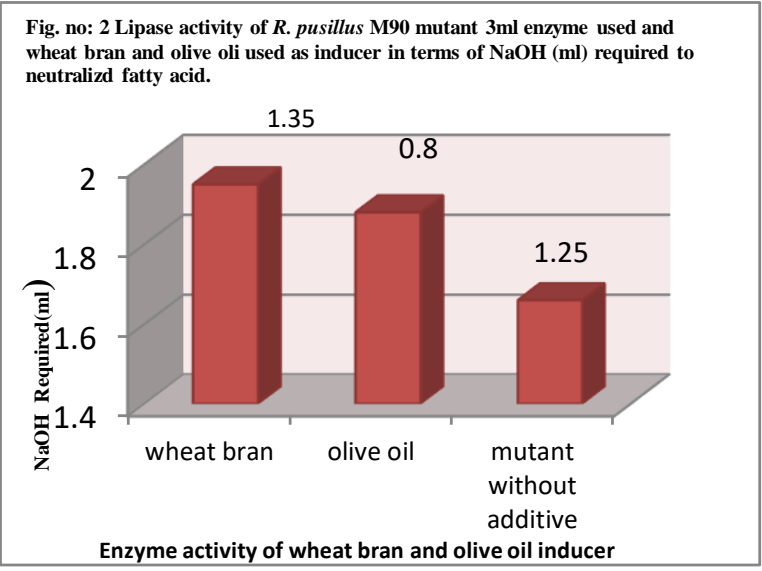

Fig. no :4 Difference in \% growth of R.pusillus as compare to control

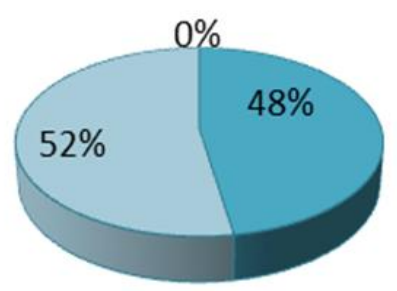

control

$\square 2 \%$ wheat bran

$\square 4 \%$ wheat bran

Fig. no. :-6 Effect of wheat bran as inducer

on growth of $R$. pusillus (colony diameter)

oil)M-90 (Wheat bran ) as inducer compared with control

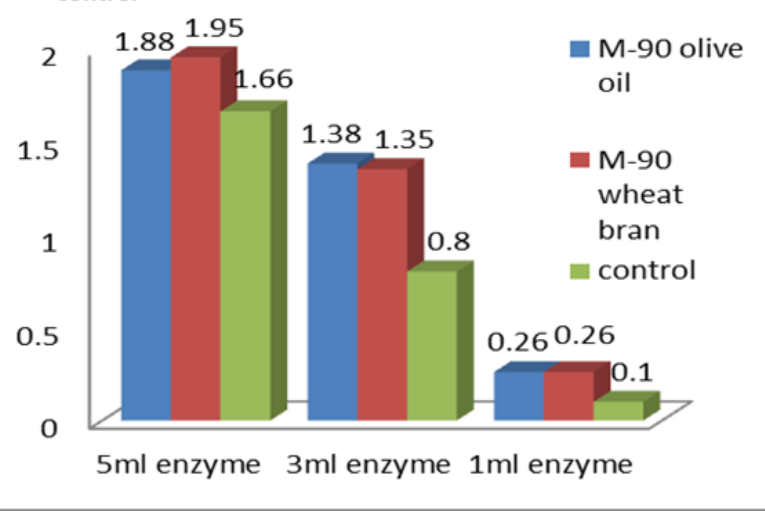

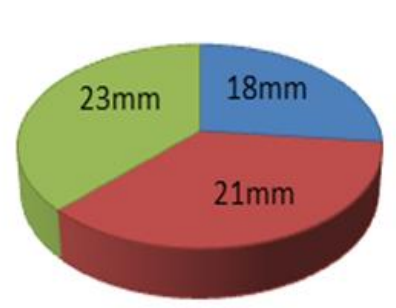

$\square$ control

$\square 2 \%$ wheat

bran

$\square 4 \%$ wheat

bran 